\author{
Artur BOROWIEC ${ }^{1}$ \\ Leonard ZIEMIAŃSKI ${ }^{2}$
}

\title{
BADANIA DYNAMICZNE ODBIERAKA PRĄDU LEKKIEGO POJAZDU SZYNOWEGO
}

\begin{abstract}
Badania dynamiczne odbieraka prądu pojazdu szynowego przeprowadzono w celu określenia parametrów modalnych projektowanego rozwiązania. Przedmiotem badań był odbierak prądu dedykowany do lekkich pojazdów szynowych (tramwaj, kolej miejska, metro) o oznaczeniu 120ECI. W celu weryfikacji modelu modalnego podczas badań porównano wyniki analiz modalnych dla różnych sposobów wymuszania drgań (losowo, impulsowo). Przeprowadzono pomiary dla pięciu położeń ślizgacza pantografu w zakresie jego pracy.
\end{abstract}

Słowa kluczowe: analiza modalna, lekki pojazd szynowy, odbierak prądu

\section{Wprowadzenie}

We współczesnych miastach komunikacja szynowa postrzegana jest jako najtańsza, a jednocześnie najbardziej ekologiczna, pomijając aspekt wytworzenia energii elektrycznej zasilającej te pojazdy. Do środków transportu szynowego miast zaliczamy tramwaje, kolej miejską i metro. W sieci komunikacyjnej dużych miast stanowią istotną rolę. Projektowanie nowych pojazdów jako odpowiedź na stale poprawiane warunki komfortu i bezpieczeństwa podróży to kolejne aspekty w tej kwestii. Sprawność obecnie eksploatowanego transportu szynowego zależy od dynamicznej kompatybilności układu pantografów z siecią trakcyjną i wynikającymi siłami kontaktu pomiędzy tymi elementami [1]. W literaturze można znaleźć wiele modeli do opisu zagadnień dynamiki górnej sieci jezdnej [1-3]. Jednym z elementów tych opisów jest model dynamiczny pantografu. Najczęściej wykorzystuje się model w postaci układu dyskretnego [2,3].

Projektowanie i analiza tego układu $\mathrm{z}$ wykorzystaniem odpowiednich procedur obliczeniowych pozwala uchwycić najważniejsze cechy dynamiczne obiektu badań. Obecnie projektowanie pojazdów szynowych to bardzo czaso-

\footnotetext{
1 Autor do korespondencji / corresponding author: Artur Borowiec, Politechnika Rzeszowska, Katedra Mechaniki Konstrukcji, ul. Poznańska 2, 35-959 Rzeszów; tel. 178651617; artur.borowiec@prz.edu.pl

${ }^{2}$ Leonard Ziemiański, Politechnika Rzeszowska, Katedra Mechaniki Konstrukcji, ul. Poznańska 2, 35-959 Rzeszów; tel. 178651353; ziele@ prz.edu.pl
} 
chłonne i odpowiedzialne zadanie. Każdy element pojazdu przed wdrożeniem do eksploatacji musi spełniać ostre wymagania norm krajowych [4,5]. Testowanie nowych produktów i ich atestowanie jest związane $\mathrm{z}$ wykonaniem szeregu prób środowiskowych weryfikujących jego odporność i trwałość. Część z weryfikacji dotyczy badań dynamicznych w tym: symulacyjne próby trwałości przy zwiększonym poziomie wibracji losowych, próby udarowe oraz próby trwałość zmęczeniowej. Jednym z podstawowych parametrów jest wyznaczenie częstotliwości drgań własnych. Współcześnie projektanci dysponują bardzo zaawansowanymi narzędziami numerycznymi. Mogą oni na etapie projektowania wstępnie zweryfikować efekty części obciążeń na modelach numerycznych. Niemniej jednak weryfikacja w laboratorium prototypów jest nieunikniona i konieczna. Wyniki takich eksperymentów mogą posłużyć do weryfikacji przyjętych modeli numerycznych lub nawet ich poprawy.

\section{Opis badań dynamicznych}

Badania zrealizowano w Laboratorium Badań Konstrukcji Wydziału Budownictwa, Inżynierii Środowiska i Architektury Politechniki Rzeszowskiej. Głównym celem był pomiar parametrów dynamicznych pantografu: częstotliwości, współczynników tłumienia oraz postaci. W trakcie prób zastosowano eksperymentalną analizę modalną [6], z pomiarem sygnału wymuszenia i odpowiedzi w przyjętych punktach pomiarowych. W praktyce estymację parametrów modelu modalnego uzyskano stosując algorytm PolyMAX [7] w dziedzinie częstotliwości. Podczas badań porównano wyniki analiz modalnych dla różnych sposobów wymuszania drgań w celu weryfikacji uzyskanego modelu modalnego układu mechanicznego. Do porównania pomierzonych postaci drgań zastosowano współczynnik MAC [8].

\subsection{Opis przedmiotu badań - pantografu}

Projektowany model odbieraka prądu to produkt oznaczony jako 120ECI, przeznaczony do lekkich pojazdów szynowych. Zaprojektowany przez firmę EC-Engineering odbierak prądu $w$ założeniach projektowych pozwala na skuteczną pracę $\mathrm{z}$ trakcją $\mathrm{w}$ zakresie od $44 \mathrm{~cm}$ do $288 \mathrm{~cm}$ nad poziom zamocowania do pojazdu [9]. Na rys. 1 przedstawiono budowę pantografu typu 120ECI. Konstrukcja mechanizmu odbieraka oparta jest na dwóch czworobokach przegubowych. Dolny czworobok składa się z ramy podstawy (1), ramienia dolnego (2), ramienia górnego (3) oraz drążka reakcyjnego (4). Górny czworobok składa się z ramienia dolnego (2), ramienia górnego (3), drążka stabilizującego (5) oraz drążka zespołu ślizgacza (6). Zespół ślizgacza (6) połączony jest z ramieniem górnym (3) podatnie z zastosowaniem zestawu sprężyn. Urządzenie poprzez zespół ślizgacza (6), dwugałęziowe aluminiowe ramię górne (3), stalowe ramię dolne (2), ramę wsporczą (1) oraz zestaw 8 linek bocznikujących przekazuje po- 
tencjał elektryczny z trakcji do przyłącza elektrycznego zainstalowanego na ramie wsporczej, służącego do połączenia odbieraka z instalacją pojazdu. Podnoszenie pantografu realizowane jest poprzez zespół napędowy (7) wyposażony w sprężynę naciągową. Siła pochodząca od sprężyny w korelacji z odpowiednio ukształtowaną krzywka napędową umożliwia nie tylko samoczynne podniesienie pantografu do maksymalnej wysokości konstrukcyjnej ale zapewnia również stały docisk zespołu ślizgacza (6) do trakcji w zakresie roboczym.

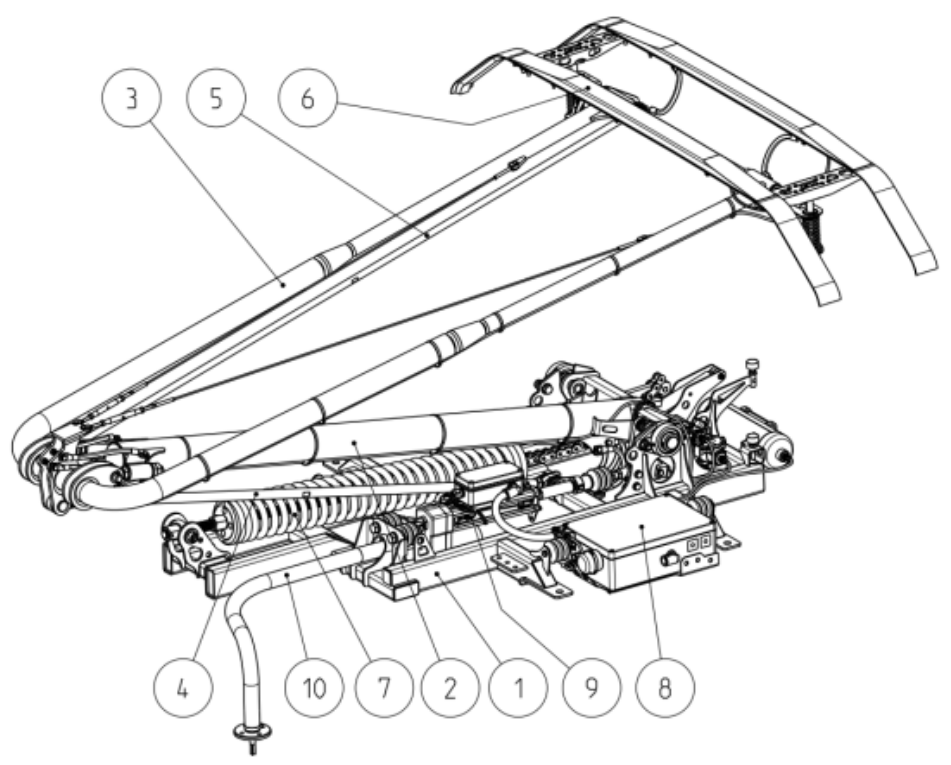

Rys. 1. Schemat pantografu typu 120ECI, na podstawie [6] (opis w tekście)

Fig. 1. Scheme of pantograph 120ECI, on the basis of [6] (description in the text)

Układ kinematyczny członów pantografu zapewnia wąską trajektorię ruchu ślizgacza w zakresie roboczym wynoszącą max $\pm 30 \mathrm{~mm}$ względem prostej pionowej przechodzącej przez punkt obrotu ślizgacza w pozycji spoczynkowej (pantograf złożony). Drążek reakcyjny (4) odpowiada za właściwą pozycję ramienia górnego (3). Natomiast drążek stabilizujący (5) steruje położeniem zespołu ślizgacza (6) i determinuje jego równoległe ułożenie względem trakcji. Opadanie pantografu realizowane jest poprzez zespół siłownika elektrycznego (9), który wysuwając się przeciwdziała sile wywieranej przez sprężynę. W ten sposób siłownik działając na odpowiedniej dźwigni poprzez układ kinematyczny doprowadza do obniżania się ślizgacza oraz ponownie napina sprężynę, akumulując w niej siłę potrzebną do kolejnego podniesienia. 


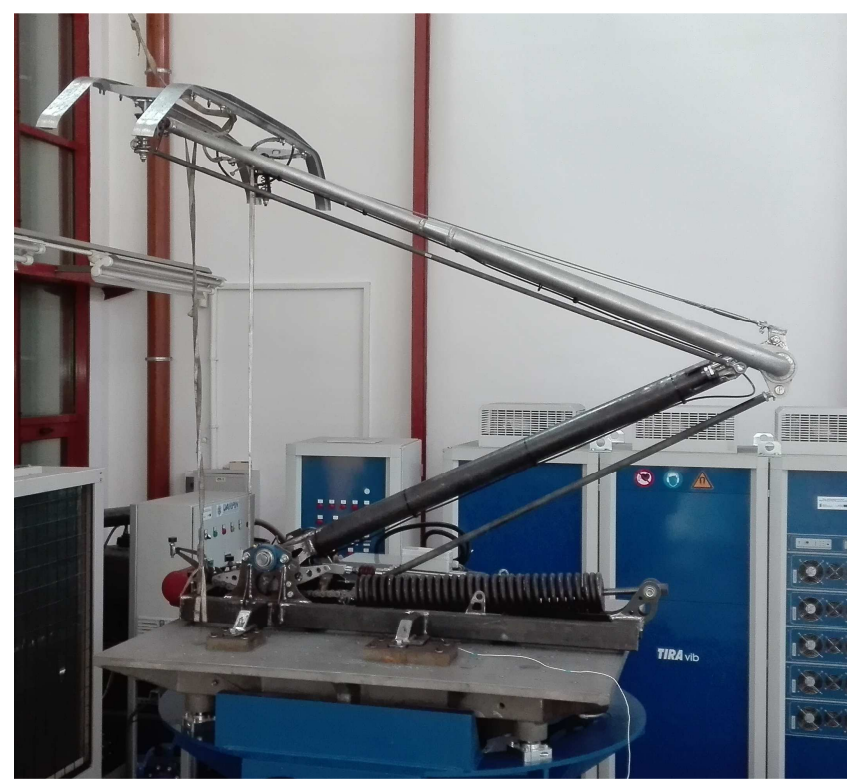

Rys. 2. Pantograf podczas badań dynamicznych

Fig. 2. Pantograph during dynamic testing

Napęd awaryjny (10) służy do ręcznego podnoszenia/opuszczania odbieraka w sytuacjach, kiedy nie ma możliwości wykonania tych operacji za pomocą elektrycznego napędu. System ADD (8) jest odpowiedzialny za awaryjne opuszczanie pantografu. Odbierak prądu z systemem ADD posiada wbudowany układ wykrywania awarii, który podczas jej wystąpienia w sposób automatyczny przejmuje sterowanie nad pracą siłownika elektrycznego, doprowadzając do niezależnego od woli motorniczego złożenia pantografu. Powyższe zastosowanie systemu uchroni w przypadku uszkodzenia mechanicznego nakładki lub też jej nadmiernego zużycia nie tylko sam pantograf, ale i sieć trakcyjną przed ewentualnymi dalszymi uszkodzeniami [6]. Całość pantografu z systemem ADD waży blisko $185 \mathrm{~kg}$. W artykule przyjęto w opisie osi pantografu nazwy zgodne z kierunkami pojazdu (wzdłużny -X, poprzeczny -Y i pionowy -Z). Na rys. 2 przedstawiono zdjęcie obiektu podczas badań dynamicznych.

\subsection{Aparatura pomiarowa}

Badania zrealizowano z wykorzystaniem aparatury Katedry Mechaniki Konstrukcji Politechniki Rzeszowskiej. Cały zestaw to dedykowany system do realizacji testów zmęczeniowych umożliwiają kompleksową ocenę wytrzymałości, jakości i trwałości elementów oraz obiektów (mechanicznych, elektrycznych i elektronicznych) poddawanych długotrwałym obciążeniom dynamicznym. 
Główne element systemu to wzbudnik elektrodynamiczny (TIRA TV 59389/AIT-440), stół ślizgowy (TGT MO 60 XXL) oraz układu sterowania zapewniającego realizację testów przestrajanym sinusem, szumem lub udarem. Zastosowany $w$ badaniach analizator to model Scadas SCR09 firmy Simens, z kartami o próbkowaniu sygnału $102,4 \mathrm{kHz}$. Wykorzystany podczas badań młotek modalny to produkt firmy PCB (T086D20). Czujniki przyspieszeń to modele o czułości $10 \mathrm{mV} / \mathrm{g}$ i $100 \mathrm{mV} / \mathrm{g}$ firm B\&K oraz PCB. Zastosowano tensometry foliowe o bazie $10 \mathrm{~mm}$ pracujące $\mathrm{w}$ układzie ćwierć-mostków firmy TENMEX. Podczas testów wykorzystano oprogramowanie TestLab firmy Simens, a w szczególności moduły: MIMO FRF Testing, Impact Testing oraz Modal Analysis.

\subsection{Metodyka badań}

W warunkach eksploatacji praca elementu odbywa się w różnych pozycjach rozłożenia. Wysokość pracy mierzy się między poziomem mocowania całego pantografu na pojeździe a górną okładziną ślizgacza, który to ma kontakt z trakcją. Podczas projektowania przyjęto wartości graniczne maksymalną $(228 \mathrm{~cm})$ i minimalną $(44 \mathrm{~cm})$ zakresu pracy odbieraka prądu. Podczas badań przyjęto pięć położeń roboczych z zakresu pracy ślizgacza:

- minimalny (P44),

- 1/4 zakresu (P105),

- 1/2 zakresu (P166),

- 3/4 zakresu $(P 227)$,

- maksymalny (P288).

Zachowanie przyjętych geometrii uzyskano za pomocą elementu z wiotkiego paska dodanego między osią ślizgacza a ramą pantografu (rys. 2). Przyspieszenia mierzono za pomocą czujników ICP jednoosiowych i trójosiowych umieszczonych na konstrukcji. Rozmieszczenie czujników oznaczono okręgami na rysunku przedstawiającym model geometryczny przyjęty w programie TestLab (rys. 3). Przyjęty zestaw pozwalał zdefiniować model eksperymentalny o 22 stopniach swobody dynamicznej. Tensometry przyklejono od góry w dwóch punktach na dolnym ramieniu pantografu. Rozmieszczenie tensometrów oznaczono rombami (rys. 3). Pierwszy u dołu ramienia dolnego wzdłuż osi rury, drugi u góry ramienia dolnego zgodnie z poprzeczną osią pantografu.

$\mathrm{W}$ badania zrealizowanych $\mathrm{w}$ laboratorium $\mathrm{z}$ zastosowaniem eksperymentalnej analizy modalnej wykorzystano wymuszenia:

- sygnałem białego szumu,

- młotkiem modalnym,

- wychylenie poprzeczne ślizgacza z położenia równowagi. 


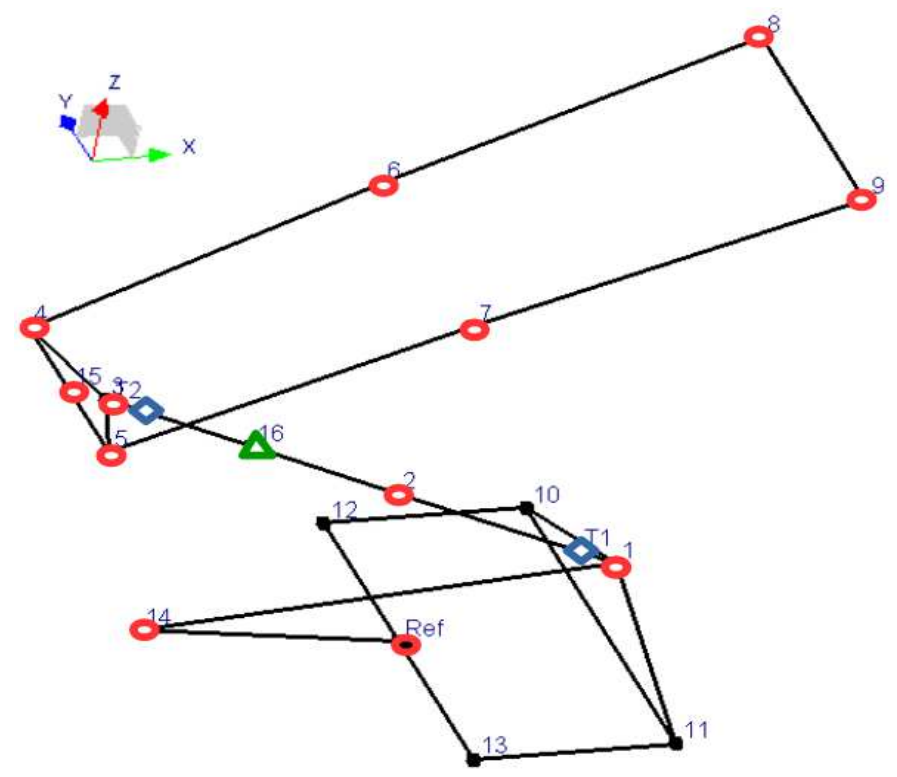

Rys. 3. Model geometryczny pantografu: okręgi - czujniki przyspieszeń; romby - tensometry; trójkąt - wymuszenie impulsowe

Fig. 3. Geometric model of pantograph: circles - acceleration sensors; diamonds - strain gauges; triangle - impulsive impulse

Wszystkie wymuszenia realizowano w kierunku poprzecznym pantografu zgodnie z osią Y modelu geometrycznego.

Sygnał losowy białego szumu generowano w zakresie 3,6 Hz-128 Hz. Biały szum charakteryzuje się stała wartością amplitud w całym pasmie częstotliwości. Dolna granica wynikała z fizycznych ograniczeń wzbudnika. Sygnał zarejestrowano po 50 powtórzeniach przy rozdzielczości $0,125 \mathrm{~Hz}$. W celu weryfikacji liniowości modelu zrealizowano trzy poziomy napięcia sterującego sygnał, odpowiednio $0,2 \mathrm{~V}, 0,3 \mathrm{~V}$ oraz $0,4 \mathrm{~V}$. Sygnał referencyjny rejestrowano na elementach w miejscu mocowania do stołu ślizgowego wzbudnika.

Wymuszenie impulsowe młotkiem modalnym realizowano na dolnym ramieniu w dwóch kierunkach prostopadle do osi rury, w punkcie oznaczonym na rys. 3 trójkątem. Kierunek oznaczony $-Y$ był zgodny z poprzecznym kierunkiem mechanizmu, a kierunek oznaczony $-Z$ był ukośny od pozostałych osi geometrii pantografu. Sygnał referencyjny rejestrowano czujnikiem siły wbudowanym w młotek. Do analiz przyjęto uśredniony sygnał z serii 10 uderzeń.

Wymuszenie poprzez wychylenie poprzeczne ślizgacza z położenia równowagi zastosowywano wg procedury z normy [5] punkt 6.4.2.2. Punkt ten dotyczy wyznaczania częstotliwości drgań poprzecznych pantografu. Wartość ta jest wykorzystywana jako wymuszenie przy weryfikacji trwałości zmęczeniowej 
podczas testu w podtrzymywanym rezonansie o liczbie $10^{7}$ cykli. Pomiar ten zakłada wychylenie poprzeczne ślizgacza $\mathrm{z}$ położenia równowagi siłą $300 \mathrm{~N}$, zwolnienie oraz pomiar $w$ trakcie swobodnych ruchów pantografu. Przy realizacji tej próby wychylenie ślizgacza wynosiło ok. $2,0 \mathrm{~cm}$. Dla tego wymuszenia jako punkt referencyjny przyjęto odczyt z jednego z czujników. Do analiz przyjęto uśredniony sygnał z serii 10 wychyleń.

\section{Wyniki pomiarów}

Zgodnie z przyjętą metodyką badań zrealizowano przyjęte w planie badań pomiary dla różnych wymuszeń konstrukcji. Z uwagi na wyraźny podział rejestrowanego widma częstotliwości na dwie grupy rezonansów podzielono cały rejestrowany zakres na dwie części. Wyniki estymacji parametrów modalnych prezentowane $\mathrm{w}$ publikacji dotyczą analiz pierwszego zakresu $3 \mathrm{~Hz}-60 \mathrm{~Hz}$. $\mathrm{W}$ tym zakresie przyjęto gęstość modalną na poziomie piętnastu biegunów układu.

\subsection{Wymuszenie białym szumem}

Wyznaczone parametry dynamiczne, wartości zidentyfikowanych częstotliwości drgań i współczynników tłumienia modalnego dla modelu P166, zestawiono w tabeli. 1 . Zwiększenie amplitudy $(0,2 \mathrm{~V}$ na $0,4 \mathrm{~V})$ sygnału wymuszenia spowodowało rejestrowane wartości wszystkich częstotliwości zmniejszyły się średnio o ok. 1,3\%. Różnica taka jest wartością zbliżoną do zastosowanej dokładności pomiarowej $0,125 \mathrm{~Hz}$. W tabeli tej dwie ostatnie kolumny zawierają obliczone wartości współczynników MAC względem wymuszenia o najmniejszej amplitudzie. Uzyskane wyniki potwierdzają zgodność otrzymanych modeli.

W celu weryfikacji charakteru układu przedstawiono na rys. 4 przykładowe przebiegi spektrum odpowiedzi i widmowych funkcji przejścia dla rożnych amplitud wymuszenia pseudolosowego białym szumem. Zauważyć można, że rejestrowane spektrum odpowiedzi jest proporcjonalne do wymuszeń. Na wykresach FRF widoczny jest spadek częstotliwości co może być związany z nieliniową sprężystością układu. Natomiast przyczyną różnic w amplitudach przebiegów FRF może być nieliniowe tłumienie. Zmiany w amplitudach mają rożne tendencje wzrostowe $(\sim 11,88 \mathrm{~Hz})$ lub spadkowe $(\sim 10,38 \mathrm{~Hz})$ niezależnie od tendencji zmian poziomu sygnału. Zastosowanie tych samych zakresów wymuszeń dla pozostałych położeń ślizgacza (P44, P105, P227, P288) potwierdziło tendencje do nieznacznego ok. 1-2\% spadku wartości rejestrowanych częstotliwości. 
Tabela 1. Wartości zidentyfikowanych częstotliwości drgań, współczynników tłumienia modalnego oraz współczynniki MAC modelu $P 166$ wymuszanego białym szumem

Table 1. The values of the identified vibration frequencies, modal damping coefficients and MAC coefficients of the $P 166$ model caused by the withe noise

\begin{tabular}{|c|c|c|c|c|c|c|c|c|}
\hline \multirow{2}{*}{ 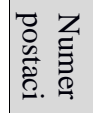 } & \multicolumn{2}{|c|}{ Wymuszenie 0,2 V } & \multicolumn{2}{|c|}{ Wymuszenie 0,3 V } & \multicolumn{2}{|c|}{ Wymuszenie 0,4 V } & \multicolumn{2}{|c|}{$M A C$} \\
\hline & $\mathrm{f}[\mathrm{Hz}]$ & $\delta[\%]$ & $\mathrm{f}[\mathrm{Hz}]$ & $\delta[\%]$ & $\mathrm{f}[\mathrm{Hz}]$ & $\delta[\%]$ & $02 \mathrm{~V}, 03 \mathrm{~V}$ & $02 \mathrm{~V}, 04 \mathrm{~V}$ \\
\hline 1. & 4,67 & 1,17 & 4,60 & 1,59 & 4,58 & 1,57 & 0,999 & 0,998 \\
\hline 2. & 6,96 & 2,58 & 6,89 & 2,85 & 6,84 & 2,34 & 0,996 & 0,980 \\
\hline 3. & 7,62 & 1,62 & 7,55 & 3,52 & 7,49 & 2,42 & 0,991 & 0,955 \\
\hline 4. & 8,53 & 1,21 & 8,45 & 1,58 & 8,38 & 1,71 & 0,999 & 0,996 \\
\hline 5. & 10,41 & 1,46 & 10,29 & 2,32 & 10,23 & 1,95 & 0,998 & 0,994 \\
\hline 6. & 11,85 & 2,69 & 11,73 & 2,39 & 11,66 & 2,13 & 0,999 & 0,997 \\
\hline 7. & 14,22 & 3,21 & 14,09 & 3,42 & 14,02 & 2,91 & 0,933 & 0,812 \\
\hline 8. & 19,17 & 0,46 & 19,20 & 0,93 & 19,23 & 0,75 & 0,925 & 0,827 \\
\hline 9. & 21,03 & 0,16 & 20,96 & 0,49 & 20,87 & 0,47 & 0,968 & 0,917 \\
\hline 10. & 30,59 & 0,92 & 30,50 & 1,44 & 30,41 & 1,23 & 0,952 & 0,920 \\
\hline 11. & 32,28 & 0,37 & 32,23 & 0,41 & 32,11 & 0,42 & 0,962 & 0,886 \\
\hline 12. & 37,50 & 2,53 & 36,61 & 2,52 & 36,59 & 2,32 & 0,964 & 0,935 \\
\hline 13. & 40,60 & 0,91 & 40,46 & 1,15 & 40,20 & 1,16 & 0,914 & 0,853 \\
\hline 14. & 44,38 & 0,24 & 44,95 & 0,38 & 44,87 & 0,39 & 0,728 & 0,636 \\
\hline 15. & 49,73 & 1,26 & 49,03 & 1,20 & 48,61 & 1,00 & 0,971 & 0,939 \\
\hline
\end{tabular}

\subsection{Wymuszenia impulsowe}

W tabeli 2. zestawiono wyniki uzyskane dla wymuszenia młotkiem oraz wychylenia pantografu w kierunku poprzecznym. W tabeli zawarto wartości współczynników MAC estymowanych postaci względem wymuszenia losowego o amplitudzie $0,3 \mathrm{~V}$. Zastosowane w eksperymencie wymuszenia impulsowe nie pozwoliły na estymacje wszystkich częstotliwości rezonansowych uzyskanych przy wymuszeniu losowym. Największą zbieżność wyników uzyskano dla czwartej postaci drgań $(8,45 \mathrm{~Hz})$. Pozostałe estymowane parametry dynamiczne różnią się co do wartości rezonansów lub ich estymowanych postaci. Różnice te można tłumaczyć kierunkiem zastosowanych wymuszeń oraz zbyt mała energią impulsu do wzbudzenia wszystkich rezonansów. Zarejestrowana pierwsza postać bardzo wyraźnie odbiega od postaci wymuszanej białym szumem. Wyniki wymuszenia impulsowego można potraktować jako zgrubne oszacowanie modelu modalnego badanego obiektu. 


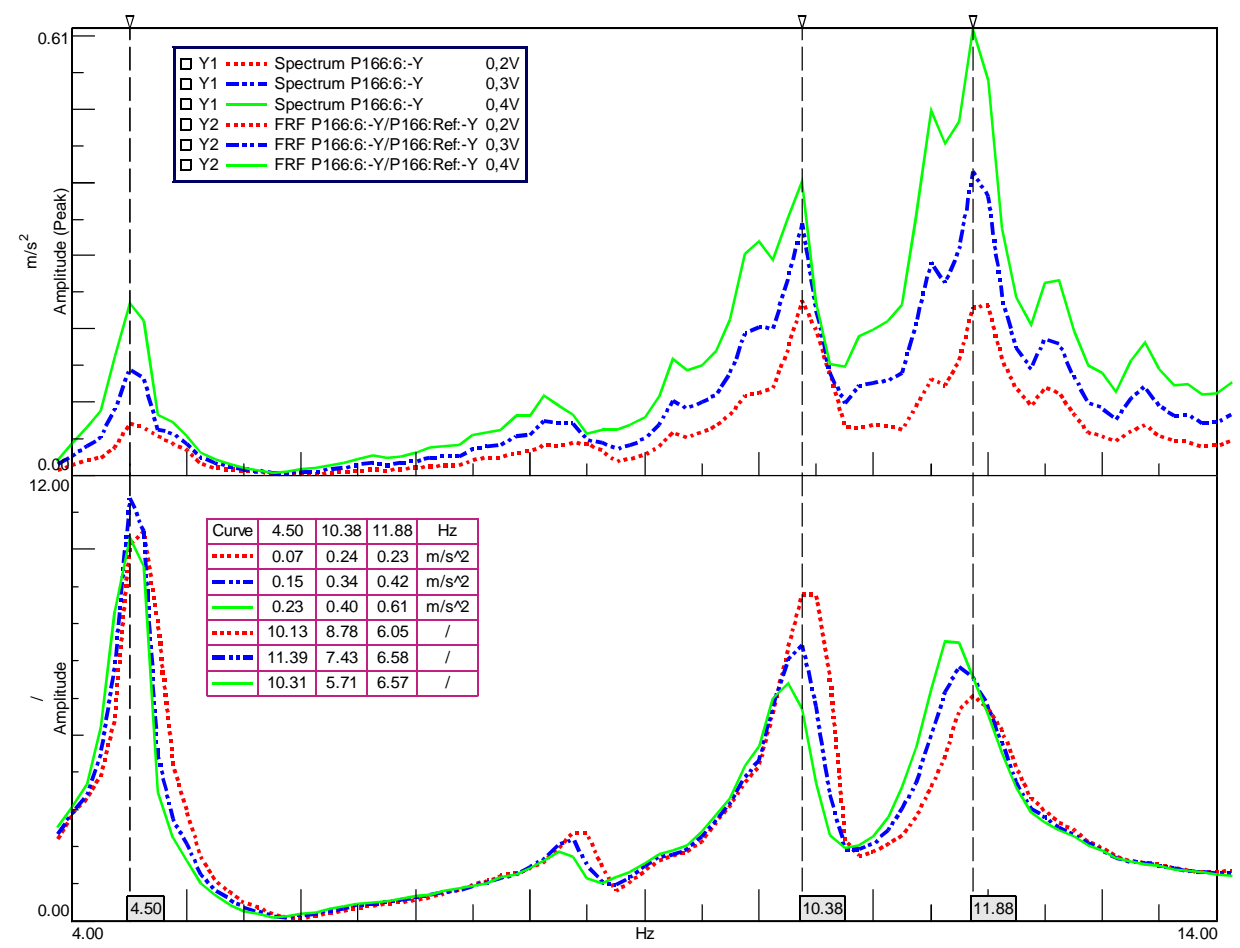

Rys. 4. Przykładowe przebiegi zmierzonych odpowiedzi w punkcie 6. modelu P166: góra - spektrum, dół - FRF

Fig. 4. Sample of measured response in point 6 of the model P166: top - spectrum, bottom - FRF

\subsection{Modele modalne w zakresie pracy pantografu}

W tabeli 3. zestawiono wyniki identyfikacji parametrów modeli modalnych dla przyjętych kilku pozycji z zakresu pracy pantografu (P44, P105, P166, P227, P288). Wszystkie wyniki w tabeli podano dla wymuszenia białym szumem o amplitudzie sygnału 0,3 V. Podczas estymacji parametrów dla modelu P105 wyznaczono tylko 14 wartości częstotliwości. Postać o numerze 2. i 3. jest tożsama $(7,37 \mathrm{~Hz})$. Zmiana kolejności postaci od 2. do 4 . w modelu P44 wynika $\mathrm{z}$ dopasowań postaci z pozostałymi modelami.

W tabeli 4. zestawiono obliczone wartości współczynnika MAC dla wszystkich rozpatrywanych modeli względem siebie. W tabeli wyróżniono wartości MAC większe niż 0,70. Ostatnia kolumna to wartość średnia MAC dla każdej ze zidentyfikowanych postaci. 
Tabela 2. Wartości zidentyfikowanych częstotliwości drgań, współczynników tłumienia modalnego oraz współczynniki MAC modelu P166 wymuszanego impulsowo

Table 2. The values of the identified vibration frequencies, modal damping coefficients and MAC coefficients of the $P 166$ model caused by the impact

\begin{tabular}{|c|c|c|c|c|c|c|c|c|c|c|c|}
\hline \multirow{3}{*}{ 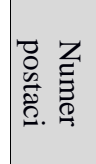 } & \multicolumn{8}{|c|}{ Wymuszenie } & \multirow{2}{*}{\multicolumn{3}{|c|}{$\begin{array}{c}\text { MAC } \\
\text { biaty szum } 0,3 \mathrm{~V}\end{array}$}} \\
\hline & \multicolumn{2}{|c|}{ b. szum 0,3 V } & \multicolumn{2}{|c|}{ mtotek $-Y$} & \multicolumn{2}{|c|}{ młotek $-Z$} & \multicolumn{2}{|c|}{ linka } & & & \\
\hline & $\mathrm{f}[\mathrm{Hz}]$ & $\delta[\%]$ & $\mathrm{f}[\mathrm{Hz}]$ & $\delta[\%]$ & $\mathrm{f}[\mathrm{Hz}]$ & $\delta[\%]$ & $\mathrm{f}[\mathrm{Hz}]$ & $\delta[\%]$ & $-Y$ & $-Z$ & linka \\
\hline 1. & 4,60 & 1,59 & 4,51 & 3.71 & 4,22 & 3,55 & 4,00 & 2,41 & 0,075 & 0,003 & 0,134 \\
\hline 2. & 6,89 & 2,85 & - & - & 6,98 & 4,33 & 7,11 & 0,43 & - & 0,923 & 0,906 \\
\hline 3. & 7,55 & 3,52 & - & - & - & - & - & - & - & - & - \\
\hline 4. & 8,45 & 1,58 & 8,50 & 1,29 & 8,58 & 0,98 & 8,45 & 1,01 & 0,984 & 0,886 & 0,939 \\
\hline 5. & 10,29 & 2,32 & 10,46 & 1,74 & - & - & 10,96 & 0,31 & 0,981 & - & 0,958 \\
\hline 6. & 11,73 & 2,39 & 11,75 & 2,30 & 10,84 & 0,50 & 13,04 & 0,75 & 0,994 & 0,490 & 0,921 \\
\hline 7. & 14,09 & 3,42 & - & - & - & - & - & - & - & - & - \\
\hline 8. & 19,20 & 0,93 & 22,74 & 2,28 & 19,48 & 0,51 & - & - & 0,138 & 0,311 & - \\
\hline 9. & 20,96 & 0,49 & - & - & - & - & - & - & - & - & - \\
\hline 10. & 30,50 & 1,44 & - & - & 30,62 & 0,47 & 30,55 & 0,67 & - & 0,720 & 0,340 \\
\hline 11. & 32,23 & 0,41 & 33,82 & 0,77 & - & - & 33,38 & 1,33 & 0,617 & - & 0,412 \\
\hline 12. & 36,61 & 2,52 & 35,75 & 2,73 & 35,80 & 0,55 & 37,02 & 0,60 & 0,776 & 0,516 & 0,876 \\
\hline 13. & 40,46 & 1,15 & - & - & 40,12 & 5,04 & 42,59 & 0,31 & - & 0,809 & 0,444 \\
\hline 14. & 44,95 & 0,38 & - & - & - & - & - & - & - & - & - \\
\hline 15. & 49,03 & 1,20 & - & - & 49,53 & 0,67 & - & - & - & 0,442 & - \\
\hline
\end{tabular}

Analizując wyniki z tabel 3-4 można zauważyć dla wszystkich modeli: bardzo dużą zgodność postaci 1. i 6., dużą zgodność postaci 4., 5. i 12. oraz duże podobieństwo postaci 2., 7., 9., 10., i 14. Zmiana geometrii, rozkładanie pantografu, właściwie nie wpływa na zmiany wartości częstotliwości postaci 3., 4., 5., oraz 7. Największe zmiany przy rozkładaniu pantografu stwierdzono dla postaci 1. (spadek 39\%), 2. (spadek 50\%) oraz 9. (spadek 24\%). Dla postaci 6. i 12. zaobserwowano niewielki wzrost wartości częstotliwości rezonansowych pantografu. Na rysunkach 5-7 przedstawiono podstawowy zestaw postaci do weryfikacji modeli numerycznych. Strzałkami znaczono składowe wektora przemieszczeń. Na rys. 5a pokazano 1. postać modelu P166. Dla tej postaci dominują przemieszczenia górnej części pantografu w kierunku poprzecznym. 
Tabela 3. Wartości zidentyfikowanych częstotliwości drgań, współczynników tłumienia modalnego modeli dla różnych poziomów położenia ślizgacza

Table 3. The values of the identified vibration frequencies, modal damping coefficients of the models of pantograph

\begin{tabular}{|c|c|c|c|c|c|c|c|c|c|c|c|}
\hline \multirow{2}{*}{ 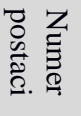 } & \multicolumn{2}{|c|}{ P44 } & \multicolumn{2}{|c|}{ P105 } & \multicolumn{2}{|c|}{ P166 } & \multicolumn{2}{|c|}{$P 227$} & \multicolumn{2}{|c|}{ P288 } & \multirow{2}{*}{$\frac{P 44-P 288}{\Delta \mathrm{f}[\%]}$} \\
\hline & $\mathrm{f}[\mathrm{Hz}]$ & $\delta[\%]$ & $\mathrm{f}[\mathrm{Hz}]$ & $\delta[\%]$ & $\mathrm{f}[\mathrm{Hz}]$ & $\delta[\%]$ & $\mathrm{f}[\mathrm{Hz}]$ & $\delta[\%]$ & $\mathrm{f}[\mathrm{Hz}]$ & $\delta[\%]$ & \\
\hline 1. & 5,81 & 1,71 & 5,36 & 1,58 & 4,60 & 1,59 & 3,99 & 3,36 & 3,56 & 2,40 & 38,7 \\
\hline 2. & 9,66 & 2,78 & 7,37 & 4,94 & 6,89 & 2,85 & 6,60 & 4,21 & 4,80 & 3,19 & 50,3 \\
\hline 3. & 7,44 & 3,48 & 7,37 & 4,94 & 7,55 & 3,52 & 7,48 & 3,17 & 7,43 & 3,30 & 0,0 \\
\hline 4. & 8,47 & 1,35 & 8,37 & 0,94 & 8,45 & 1,58 & 8,50 & 1,74 & 8,77 & 1,57 & $-3,5$ \\
\hline 5. & 10,38 & 3,64 & 10,33 & 3,00 & 10,29 & 2,32 & 10,48 & 2,96 & 10,72 & 3,71 & $-3,3$ \\
\hline 6. & 11,67 & 3,01 & 11,46 & 1,69 & 11,73 & 2,39 & 11,95 & 1,98 & 12,59 & 1,33 & $-7,8$ \\
\hline 7. & 14,12 & 1,01 & 14,21 & 3,27 & 14,09 & 3,42 & 14,13 & 2,98 & 14,20 & 2,51 & $-0,6$ \\
\hline 8. & 19,76 & 0,23 & 20,31 & 0,12 & 19,20 & 0,93 & 18,45 & 0,69 & 17,27 & 0,58 & 12,6 \\
\hline 9. & 24,77 & 0,30 & 22,03 & 0,55 & 20,96 & 0,49 & 19,89 & 0,49 & 18,92 & 0,31 & 23,6 \\
\hline 10. & 30,76 & 1,62 & 32,53 & 0,98 & 30,50 & 1,44 & 28,83 & 0,95 & 28,37 & 0,93 & 7,8 \\
\hline 11. & 34,49 & 1,62 & 33,00 & 0,29 & 32,23 & 0,41 & 31,36 & 0,41 & 30,53 & 0,29 & 11,5 \\
\hline 12. & 35,48 & 0,12 & 36,04 & 1,69 & 36,61 & 2,52 & 37,63 & 1,39 & 38,79 & 0,09 & $-9,3$ \\
\hline 13. & 39,94 & 0,28 & 40,10 & 0,52 & 40,46 & 1,15 & 40,94 & 0,68 & 41,29 & 1,39 & $-3,4$ \\
\hline 14. & 45,14 & 0,28 & 45,14 & 0,37 & 44,95 & 0,38 & 44,15 & 0,41 & 43,22 & 0,59 & 4,3 \\
\hline 15. & 50,79 & 0,19 & 50,13 & 0,94 & 49,03 & 1,20 & 48,64 & 1,30 & 49,06 & 0,64 & 3,4 \\
\hline
\end{tabular}

Rysunek 5b. zawiera postać 2., dla której dominują pionowe przemieszczenia górnej części. Na rys. 6a pokazano 4. postać modelu P166. Dla tej postaci dominują przemieszczenia skrętne górnej części pantografu z ruchem węzłów w pionie. Rysunek 6b. zawiera postać 5., dla której dominują ruchy poprzeczne środkowej części pantografu przy jednoczesnym rezonansie górnego stabilizatora $\mathrm{z}$ tendencją do niesymetrycznego skręcania osi ślizgacza. Na rys. 7a pokazano 6. postać modelu P166. Dla tej postaci dominują ruchy poprzeczne środkowej części pantografu przy jednoczesnym rezonansie górnego stabilizatora z tendencją do symetrycznego skręcania osi ślizgacza. Forma ta charakteryzuje się największymi wartościami przemieszczeń ze wszystkich obserwowanych postaci. Rysunek 7b. zawiera postać 12., dla której dominuje zginanie górnej części pantografu. 
Tabela 4. Wartości współczynniki MAC dla różnych poziomów rozłożenia pantografu Table 4. The values of the MAC coefficients of a models of pantograph

\begin{tabular}{|c|c|c|c|c|c|c|c|c|c|c|c|}
\hline \multirow{2}{*}{ 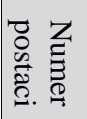 } & \multicolumn{4}{|c|}{ P44 } & \multicolumn{3}{|c|}{ P105 } & \multicolumn{2}{|c|}{ P166 } & \multirow{2}{*}{$\begin{array}{l}\text { P227 } \\
\text { P288 }\end{array}$} & \multirow{2}{*}{ 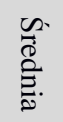 } \\
\hline & P105 & P166 & P227 & P288 & P166 & P227 & P288 & P227 & P288 & & \\
\hline 1. & 0,92 & 0,94 & 0,90 & 0,84 & 0,96 & 0,94 & 0,94 & 0,99 & 0,95 & 0,95 & 0,93 \\
\hline 2. & 0,54 & 0,56 & 0,47 & 0,39 & 0,74 & 0,74 & 0,69 & 0,90 & 0,81 & 0,85 & 0,67 \\
\hline 3. & 0,40 & 0,36 & 0,31 & 0,10 & 0,64 & 0,24 & 0,07 & 0,73 & 0,31 & 0,46 & 0,36 \\
\hline 4. & 0,76 & 0,73 & 0,67 & 0,64 & 0,95 & 0,94 & 0,93 & 0,99 & 0,98 & 0,99 & 0,86 \\
\hline 5. & 0,91 & 0,86 & 0,87 & 0,74 & 0,98 & 0,94 & 0,72 & 0,97 & 0,74 & 0,82 & $\mathbf{0 , 8 5}$ \\
\hline 6. & 0,94 & 0,93 & 0,89 & 0,86 & 0,97 & 0,94 & 0,88 & 0,99 & 0,96 & 0,98 & $\mathbf{0 , 9 3}$ \\
\hline 7. & 0,75 & 0,31 & 0,54 & 0,64 & 0,45 & 0,66 & 0,60 & 0,72 & 0,54 & 0,84 & 0,60 \\
\hline 8. & 0,28 & 0,01 & 0,01 & 0,10 & 0,28 & 0,34 & 0,18 & 0,86 & 0,55 & 0,81 & 0,34 \\
\hline 9. & 0,59 & 0,43 & 0,26 & 0,14 & 0,75 & 0,71 & 0,60 & 0,91 & 0,75 & 0,92 & 0,60 \\
\hline 10. & 0,20 & 0,34 & 0,46 & 0,53 & 0,80 & 0,58 & 0,64 & 0,87 & 0,77 & 0,87 & 0,61 \\
\hline 11. & 0,49 & 0,38 & 0,16 & 0,04 & 0,90 & 0,52 & 0,20 & 0,79 & 0,31 & 0,55 & 0,43 \\
\hline 12. & 0,48 & 0,62 & 0,63 & 0,61 & 0,81 & 0,70 & 0,61 & 0,95 & 0,92 & 0,96 & 0,73 \\
\hline 13. & 0,55 & 0,53 & 0,25 & 0,06 & 0,83 & 0,57 & 0,35 & 0,64 & 0,34 & 0,85 & 0,50 \\
\hline 14. & 0,87 & 0,80 & 0,54 & 0,25 & 0,86 & 0,59 & 0,32 & 0,77 & 0,39 & 0,71 & 0,61 \\
\hline 15. & 0,62 & 0,32 & 0,18 & 0,10 & 0,71 & 0,45 & 0,24 & 0,84 & 0,33 & 0,58 & 0,44 \\
\hline
\end{tabular}

a) $4,60 \mathrm{~Hz}$

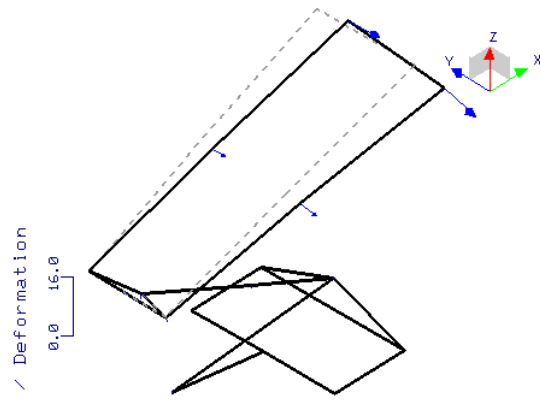

b) $6,89 \mathrm{~Hz}$

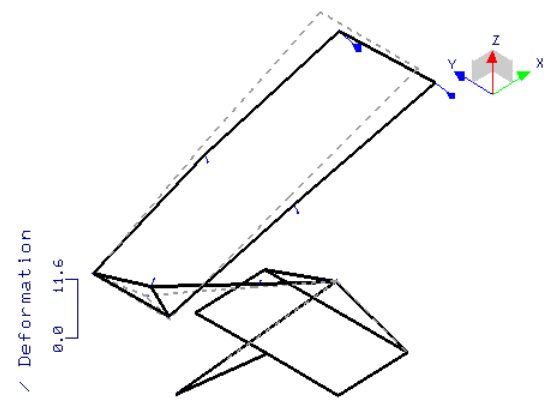

Rys. 5. Pomierzone formy modelu P166: (a) pierwsza oraz (b) druga

Fig. 5. Measured forms of model P166: (a) first and (b) second 
a) $8,45 \mathrm{~Hz}$

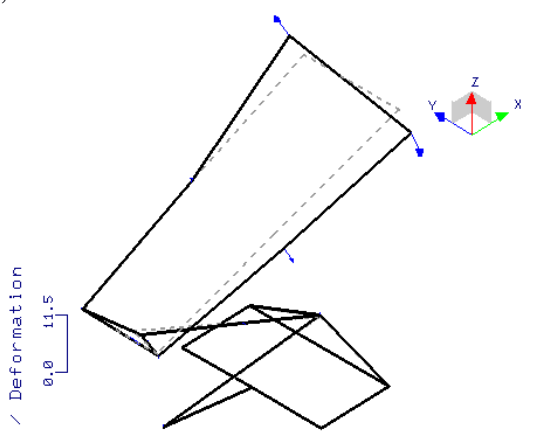

b) $10,29 \mathrm{~Hz}$

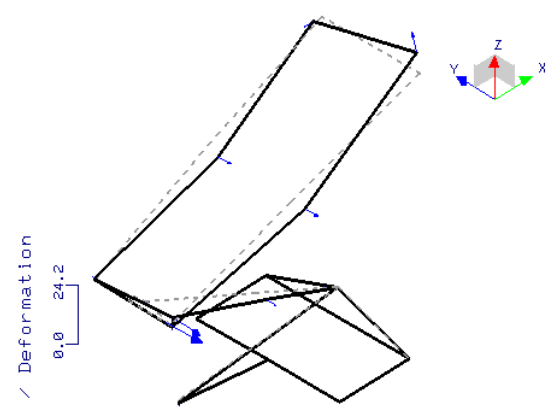

Rys. 6. Pomierzone formy modelu P166: (a) czwarta oraz (b) piąta

Fig. 6. Measured forms of model P166: (a) fourth and (b) fifth

a) $11,73 \mathrm{~Hz}$

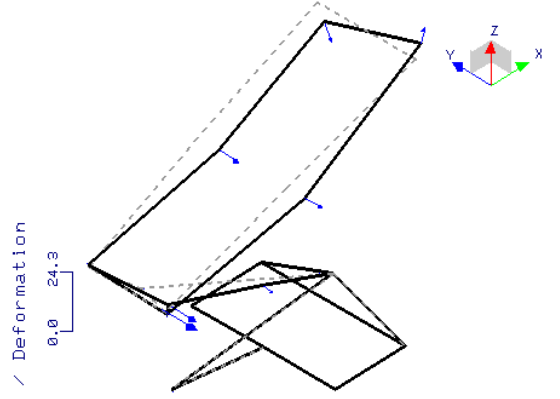

b) $36,61 \mathrm{~Hz}$

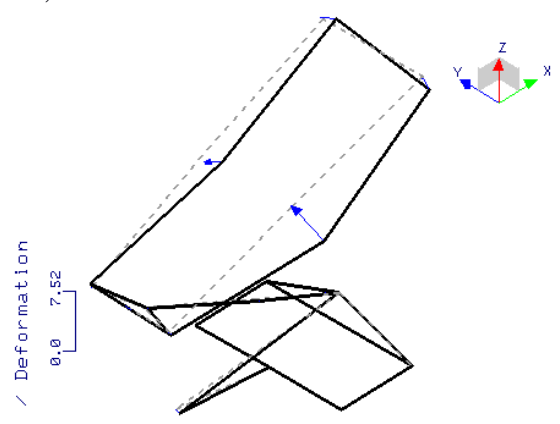

Rys. 7. Pomierzone formy modelu P166: (a) szósta oraz (b) dwunasta

Fig. 7. Measured forms of model P166: (a) sixth and (b) twelfth

\section{Podsumowanie}

Uzyskane wyniki analizy modalnej wdrażanego odbieraka prądu pozwoliły na wyznaczenie jego modelu modalnego. Porównanie modeli modalnych dla różnych poziomów rozłożenia pozwala wskazać, że kilka postaci ma zgodne formy w większości nieznacznie różniąc się wartościami częstotliwości. Można stwierdzić, że są to podstawowe formy drgań pantografu niezależnie od zakresu jego rozłożenia $(1.3,6-5,8 \mathrm{~Hz}, 2.4,8-9,7 \mathrm{~Hz}, 4.8,5-8,8 \mathrm{~Hz}, 5.10,3-10,7 \mathrm{~Hz}$, 6. $11,5-12,6 \mathrm{~Hz}, 12.35,5-38,8 \mathrm{~Hz})$. Wartości tych rezonansów zestawiono w tabeli. 3., a skale podobieństw form zestawiono w tabeli 4. Pozostałe rezonansowe w większym stopniu zmieniają postacie drgań. Zastosowanie wymuszenia impulsowego potwierdziło część uzyskanych rezultatów wymuszenia losowego. Przedstawione $\mathrm{w}$ artykule wyniki zostaną zastosowane do weryfikacji modeli numerycznych pantografu. 


\section{Podziękowania}

Do badań wykorzystano aparaturę zakupiona w projekcie nr POPW.01.03.00-18-012/09 z Funduszy Strukturalnych w ramach Programu Operacyjnego Rozwój Polski Wschodniej wspótfinansowanego przez Unię Europejska ze środków Europejskiego Funduszu Rozwoju Regionalnego.

\section{Literatura}

[1] Ambrósio J., Pombo J., Pereira M., Antunes P., Mósca A.: A Computational Procedure for the Dynamic Analysis of the Catenary-Pantograph Interaction in High-Speed Trains, Journal of Theoretical and Applied Mechanics, 50, 3, pp. 681-699, 2012.

[2] Lopez-Garcia O., Carnicero A., Marono J. L.: Influence of stiffness and contact modelling on catenary-pantograph system dynamics, Journal of Sound and Vibration, 299, 2007, pp. 806-821.

[3] Bautista A, Montesinos J, Pintado P.: Dynamic interaction between pantograph and rigid overhead lines using a coupled FEM - multibody procedure, Mechanism and Machine Theory 97, 2016, pp. 100-111.

[4] PN-EN 61373 (2011) - Zastosowania kolejowe - Wyposażenie taboru kolejowego Badania odporności na udary mechaniczne i wibracje.

[5] PN-EN 50206-2:2010 - Zastosowania kolejowe - Tabor - Pantografy: Charakterystyki i badania - Część 2: Pantografy metra i lekkich pojazdów szynowych.

[6] Ewins D.J.: Modal Testing: Theory and Practice, Research Studies Press, Baldock, 2000.

[7] Peetersa B, Van der Auweraera H, Guillaumeb P., Leuridana J, The PolyMAX frequency-domain method: a new standard for modal parameter estimation?, Shock and Vibration 11, 2004, pp. 395-409.

[8] Allemang R. J., Brown D. L., A Correlation Coefficient for Modal Vector Analysis, Proc. of the 1st IMAC, 1982, pp. 110-116.

[9] Dokumentacja tech.-rozruchowa odbieraka prądu 120ECI, EC-Engenering, 2017.

\section{DYNAMIC TESTING A PANTOGRAPH OF LIGHT RAIL VEHICLE}

\section{S u m m a r y}

Dynamic testing of the rail vehicle current collector (pantograph) was conducted to determine the modal parameters of the proposed solution. The subject of the study was a current receiver dedicated to light rail vehicles marked 120ECI. In order to verify the modal model, the results of the modal analyzes for different vibration induction methods (random, pulsed) were compared. Measures were taken for the five positions of the collector head in its working range.

Keywords: modal analysis, light rail vehicle, pantograph

Przestano do redakcji:19.03.2017 $r$.

Przyjęto do druku: 28.04.2017 r. 